\title{
Competitiveness as the Basis of EU Regional Policy: Smart Specialization and Sustainability
}

\author{
By Mykola Palinchak ${ }^{1}$, Myroslava Tsalan ${ }^{1}$, Kateryna Brenzovych ${ }^{1}$, \\ Anatolii Kucher², Tomáš Kajánek ${ }^{3}$, Martin Grešš ${ }^{3}$
}

\begin{abstract}
Nowadays in the globalization era countries are forced to pay considerable attention to the integration aspects of development, regionalization processes ensuring their own competitiveness in order to enhance the competitive position in the market, which increases the scientific interest in the study of these issues. The purpose of the article is to consider competitiveness as the basis of EU regional policy and to determine the possibilities of applying such experience in Ukraine. A number of scientific research methods have been used: the method of deduction and induction, analysis, synthesis and comparison, a graphic method. Globalization contributes to the creation of new conditions of the world economic development, which forces economic actors to reconsider their role in the economy. Competitiveness provides them with a reliable competitive positions today and in the future. The high competitiveness of the region testifies to the effective organization and optimization of economic processes. EU regional policy takes into account that the competitiveness of the region is formed in the conditions of competitive relations at the national and international levels. The EU regional policy experience can be implemented in the Ukrainian regional policy. The competitiveness of the region allows to respond in time to market changes. EU regional policy takes this into account, so the category of regional competitiveness is paid much attention on as confirmed by the RCI calculation. The possibilities of increasing the competitiveness and sustainability of regions through the development of smart specialization and implementation of smart projects are outlined. The advantages of implementing European experience in the development of competitiveness of regions on the basis of smart specialization in Ukraine are proved.
\end{abstract}

Keywords: competitiveness, European Union, regional policy, European regional competitiveness index, smart specialization.

\section{Introduction}

One of the most important characteristics of modern world economy development is the active implementation of globalization processes. Globalization defines the transnational, global content of the international economic system, which operates on the basis of established laws. Globalization is accelerating the merger of individual commodity markets. Information, knowledge and information technologies are the sources of efficiency and productivity enhancement. Under the influence of globalization, the liberalization of entry into foreign markets and the conduction of foreign economic activity takes place, which actualizes the issue of competition of countries in the world market. Globalization, on the one hand, provides many opportunities for participants, and on the other hand, creates many challenges and 
threats, often encouraging countries to participate in integration groups. Thus, countries are forced to pay more attention to competitiveness issues in order to strengthen their competitive position in the market. This points to the topicality of the study.

A literature review shows that a certain contribution to the study of the formation and implementation of a competitive regional policy in the context of the development of smart specialization and globalization of trade was made by scientists: A. Alieva [1], P. Annoni, L. Dukstra [2], O. Berezina [3], Y. Bilan, V. Nitsenko, O. Yatsenko et all. [4, 5, 24, 31, 32], N. Cherkas [8], M. Kogut-Jaworska, E. Ociepa-Kicińska [17], V. Kujbida, L. Fedulova [18], A. Polido, S. M. Pires, C. Rodrigues, F. Teles [22], S. Semiv, Y. Berezivskiy, I. Baranyak et all. [28], T. Vasyltsiv, R. Lupak, M. Kunytska-Iliash et all. [30]. However, and despite the recurrent sustainable development, the issue of competitiveness as the basis of EU regional policy in context of smart specialization and sustainability is insufficiently studied.

\section{Materials and Methods}

Nowadays only competitive entities can occupy and retain relevant competitive positions in a market environment, often because of their potential enhancing within integration structures. At the same time, this experience can be useful for countries that are working to improve their competitiveness, including the regional development policy improving.

Therefore, the purpose of the article is to consider competitiveness as the basis of EU regional policy and to determine the possibilities of applying this experience to Ukraine in the context of the implementation of the European integration strategy.

To achieve this goal, a number of scientific research methods have been used, and namely:

- the deductive method - to consider common theoretical approaches while determining competitiveness and directly examining regional competitiveness in the EU;

- the inductive method - when identifying opportunities to apply the experience of EU regional development in Ukraine's regional policy;

- the method of analysis and synthesis - in the processing of statistical information, which reflects the dynamics of spending the EU budget on competitiveness, the indicator of the regional competitiveness index by activity and by all regions of the EU Member States;

- the method of comparison, by means of which comparative analysis of the indicators of the regional competitiveness index within the time period and EU member states has been made;

- the graphic method - for visual research results display.

\section{Results}

Competitiveness is an important multidimensional hierarchical economic category that is explored in different ways. In a broad sense, competitiveness is the presence of strong, stable positions in the market $[16,26]$. According to the definition of the Organization for Economic Cooperation and Development, competitiveness should 
be understood as the ability of companies, industries, regions and nations to generate high levels of income and remuneration, while remaining open to international competition [19].

As Yu. Kyryllov emphasizes, a new paradigm of competitive development is being formed in the context of globalization, when each economic activity of different level and sphere of activity should be oriented at its level of development and competitiveness. Thus, nowadays measures should be taken to ensure competitive development of both individual firms, countries and regional integration groups.

Recently, much attention has been paid to regions in the context of globalization processes. As we know, the benefits of globalization are distributed unevenly. Stronger entities strengthen their competitive positions, while weaker ones suffer from it. One way to remedy the situation is to combine potentials in the form of regional integration structures, which allows to achieve synergistic effect and is manifested in the processes of regionalization. In the context of globalization, regions are getting a new role in the economy. They are changing their tasks, in particular they must achieve the highest possible levels of competitiveness in the national and international dimensions. Now regions have become independent entities of economic relations and are not simply a competitive environment for enterprises.

The progressive aggravation of globalization trends also leads to the formation of a new paradigm of regional development, which is based on creating the conditions for selfdevelopment of territories, effective use of their competitive advantages, which requires a deeper understanding of the regional competitiveness concept [6].

In literary sources, the competitiveness of a region is defined differently, taking into account available resources, the presence of infrastructure, institutional component and the advantages of public-private partnership. The competitiveness of a region is the ability of the regional economic system to optimize local resources in order to compete successfully in national and international markets and respond adequately and promptly to changes occurring in those markets [7]. It is important to note that this approach focuses on measures aimed at ensuring the ability to compete with competitors in national and international markets, the ability to adapt to changes and to cope with them. On the other hand, competitiveness in terms of competitive advantages is considered as having certain higher characteristics of the region in comparison with others. It is characterized by inter-regional differences in the level of innovative development, foreign direct investment inflows, development of small and medium-sized enterprises and infrastructure, availability of skilled personnel, the level of labor productivity and employment [23]. In fact, the competitiveness of a region is an integral indicator, the level of which depends on the state of individual economic indicators that characterize the development of the region and are taken into account in its calculation. When determining the competitiveness of a region, they are often guided by the indicators of the functioning of industries and the activities of production structures, which determine their constant development and success in competition in the domestic and foreign markets. It is estimated by the level of competitiveness of its individual enterprises and their products [27].

Competitiveness is an economic category that characterizes the development of a region, based on an analysis of indicators or dynamics, and even better, on the basis of 
comparisons of identical indicators of other regions. That is why regular rating of regions is carried out in order to determine the location of a particular region among others, the reasons for such positions and to develop measures for their preservation or improvement. In the context of regionalization processes, it is important to develop an adequate and correct regional policy focused on ensuring the competitiveness of the region, which is often influenced by the results of the rating processes of the regions.

The European Union is one of the major players at the regional level in the international arena. The notion of regionality in the EU has a dual meaning. On the one hand, the EU as a whole, is the only politico-economic region linked by a common legal and regulatory framework, territorial unity and civilizational dimensions, and on the other hand, it is an aggregate of smaller regions that seek to satisfy their own intra-territorial interests locally. The EU is an example of a regional integration structure that combines the economic, political and social potential of the participating countries to make it a powerful partner and competitor in a globalized space.

Today, EU regional policy is a cohesion policy with the aim of improving the economic well-being of regions and to minimize existing regional disparities. Throughout its history, EU regional policy has been changed. At the time of its inception, it was a policy of rapprochement between regions in the context of their territorial approximation, which was manifested in the form of the implementation of individual infrastructure development programs. This has helped to stimulate business activity in EU regions. Subsequently, this policy transformed into a conscious policy of grouping regions. This was not the last transformation of regional development policy. In fact, competitiveness is, and must be, the focus of EU regional development policy. In order to ensure this, transformational changes are taking place both in the economic environment and in the adaptation of EU regional policy to them. Today, under the influence of globalization, transnationalization, internationalization and integration processes, EU regional policy has been changed once again. Being created in the form of extraordinary measures, today regional policy is a constant factor without which full integration is impossible. Now EU regional policy is geared towards creating regions more competitive, fostering economic growth and creating new jobs [25].

Each year, EU funding for competitiveness increases. In the EU budget, this spending line is somewhat broader, combined with the issue of growth and employment and is called "Competitiveness for growth and jobs". Overall, growth and employment are economic categories affecting competitive development. The dynamics of changes in EU budget expenditures in this area is shown in Figure 1.

The data in Figure 1 indicate that the EU is paying attention to competitiveness issues and, wherever possible, is increasing its spendings on this area.

It can now be argued that a new EU regional policy has been formed, which has acquired new features and is based on specific principles, among which are the following: - recognizing that growth opportunities exist throughout the territory, in all types of regions;

- focus on promoting endogenous assets as a source and basis of regional development, rather than on exogenous investments and transfers. Particular attention should be paid to this approach, since regional development policy is aimed at enhancing the economic potential of the regions themselves, which gives them motivation to take care of 
themselves and their prospects independently;

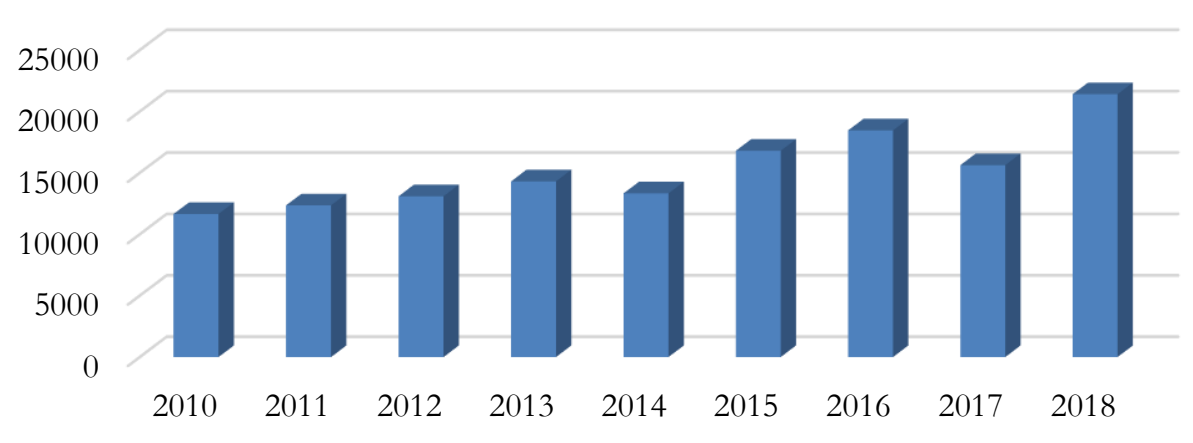

Figure 1: EU budget expenditures on "Competitiveness for Growth and Jobs" in 20102018, EUR million

Source: built by the authors on the basis of [9].

- the benefit of identifying and harnessing growth opportunities rather than counteracting the effects of decline. A distinctive feature of EU policies as a whole is that they learn from their mistakes and skillfully take preventative measures to prevent the repetition of negative processes within their economic system;

- an understanding of the growth opportunities that exist throughout the territory and in all types of regions, and a clear emphasis on strengthening regional competitiveness;

- the need for long-term strategies aimed at the wider local environment;

- a bottom-up approach and coordinated multi-level governance with a stronger role for local and regional actors, including business and other social partners;

- special attention to such "soft" factors of development as competencies, innovative opportunities of business and public sector, inter-company network interactions;

- a new understanding and approaches to measuring economic growth with a focus on its quality and broader social and environmental impacts [18].

The principles outlined reflect those of functioning of the modern world economic system, in terms of the dominant importance of innovative technological, social and environmental components of competitiveness, but at the same time, in our opinion, the need to develop long-term development strategies is debatable. We are more inclined to say that long-term strategic directions must be in place, but constant monitoring and smaller periods of analysis and adjustment should necessarily be foreseen. This is due to frequent changes in the environment of the entities functioning, many factors whose set and force of influence change over time, which requires appropriate timely analysis and corrective actions.

Scholars have already identified trends in the development of a new regional policy of the European Union. The most significant of them according to scientists are the following [18]:

- observance of the established European values;

- stimulating economic growth and improving the quality of life on the basis of strategic investments; 
- changes in the formation of the European budget;

- an innovative imperative for EU regional development;

- regional strategic programs;

- strengthening of the external integration of the regions.

Regional development in the EU is examined at two levels: at the national level, when Member States are considered as regions of the European Union's integrated system and at the intra-regional level of EU Member States. Regional competitiveness is the ability of a region to offer an attractive and sustainable environment for businesses and residents to live and work [2]. In order to monitor and evaluate the level of development, dynamics and location among other regions in the European Union, the Regional Competitiveness Index (RCI) calculation initiative has been launched every three years. This indicator shows the state of affairs in such important areas as health or human capital, innovation, transport, governance, digital infrastructure. The Regional Competitiveness Index is a comprehensive indicator that includes three sub-indices, and namely:

- basic sub-index (Institutions, Macroeconomic stability, Infrastructure, Health, Basic Education);

- efficiency sub-index (Higher Education and Lifelong Learning, Labour market efficiency, Market size);

- innovation sub-index (Technological readiness, Business sophistication, Innovation).

It is important to note that it is difficult to analyze the dynamics of the RCI on a time dimension, as changes to the components of the calculation are made, some indicators are no longer available while others are available for consideration. Therefore, the dynamics of the RCI in terms of subindex components in 2016 and 2019 are shown in Figure 2.

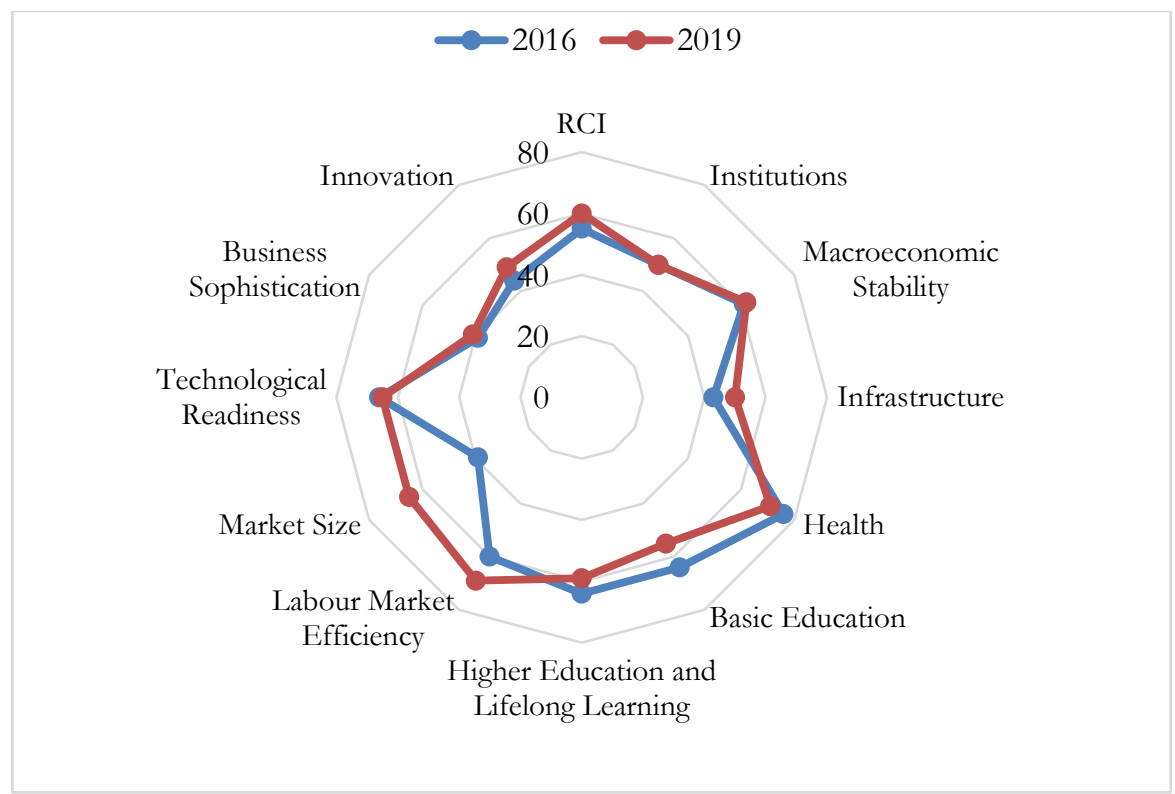

Figure 2: RCI (EU average) by Component of Subindices in 2016 and 2019 
Source: built by the authors on the basis of $[13,14]$.

The data presented in Figure 2 demonstrate that the economic processes occurring in the EU have different effects on the constituents of subindices. The subindex component indicators are characterized by varying degrees of sensitivity to EU economic policy and reform. The overall RCI changed by $9 \%$ over 3 years. Of the 11 components considered, only 1 indicator remained unchanged, 6 - increased, 4 - decreased. Growth has taken place in such areas as Institutions, Labor Market Efficiency, Market Size, Innovation. The decline is taking place in such important social areas as: Health, Basic Education, Higher Education and Lifelong Learning.

RCI scores of all regions are interesting for analysis. As it is known, the regional score is a measurement of the relationship of the regional RCI value to the EU RCI mean (average), measured in terms of standard deviations from the mean [2]. A comparison of RCI scores of all regions in 2013 and 2019 is shown in Figure 3.

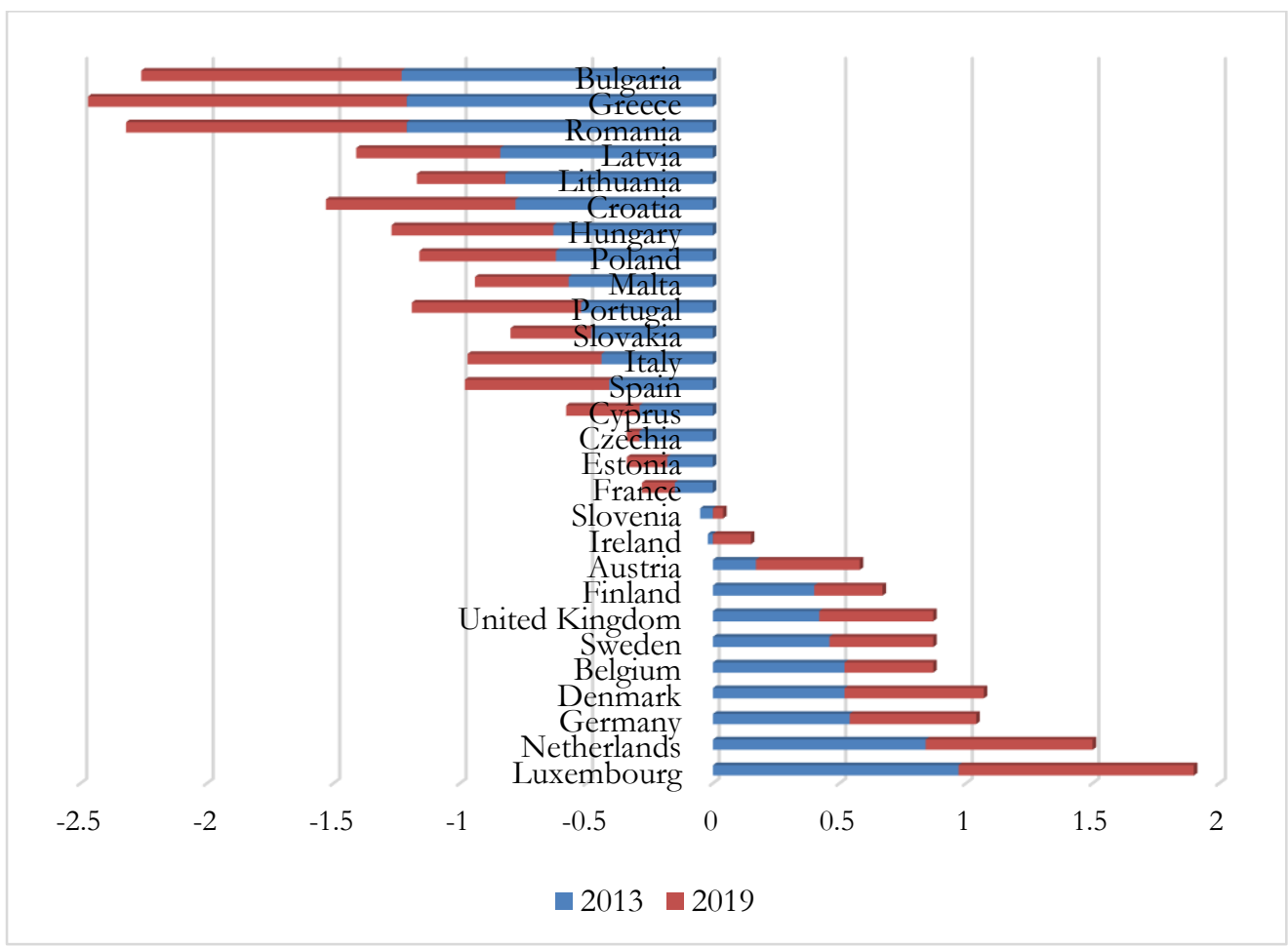

Figure 3: RCI scores of all regions in 2013 and 2019

Source: built by the authors on the basis of [10].

As it can be seen from Figure 3, this indicator was negative for 19 countries in 2013 and 17 countries in 2019. It is lower than the EU average score. Accordingly, for 9 countries in 2013 and 11 countries in 2019 this indicator was positive. That is, it exceeds the EU average score in these countries. Only in two countries during this period the indicator's value has changed from negative to positive. These are Slovenia and Ireland. In 23 regions, changes were more than $5 \%$. But at the same time, as in Figure 2, so in Figure 3 
individual indicator's values have undergone slight changes, which may be due to methodological changes in the RCI calculation, and therefore it is difficult to determine the significance of their impact and to draw informative conclusions about them.

A deep analysis of such indicators enables Member States' authorities and EU institutions to build on current and prospective regional policies and develop appropriate programs on their basis. It is gratifying that the establishment of regional aspects of development in the EU is based on careful negotiation and discussion of priorities between the European Parliament, the European Commission and the Member States. In addition, we take it for granted that the opinion of citizens is taken into consideration. The public is a key indicator of reform performance and a perspective-need barometer. In addition, in the EU, citizens' opinions are also taken into account through various polls on regional development.

According to the Eurobarometer Flash survey, $40 \%$ of Europeans are aware of regional development programs, $81 \%$ of whom recognize their positive impact on their lives. The citizens who participated in the survey have noted:

- increase investment in education, health and social infrastructure. $91 \%$ of the respondents emphasized this;

- more attention should be given to the environment (90\% of those surveyed emphasized it);

- special attention should be paid to unemployment in individual regions $(69 \%$ of those polled are worried about it), deprived urban areas (54\% of those polled note) and remote and mountain areas (52\% of polled) [12]. We consider this practice to be further developed, taking into account the views of citizens and raising their awareness of EU regional development plans and programs. Based on the information received from the public, it is easier to solve current problems, understanding how they affect the interests of ordinary citizens and build a strategy for future development.

Today, within the European Union, increasing attention is being paid to the concept of smart specialization, which is focused on stimulating the maximum use of the opportunities and potential of the region, the activation of local entrepreneurial initiatives and technological innovation. The Smart specialization strategy has structured a revolution in the field of innovative regional policy [8]. According to O. Berezina, the strategy of smart specialization involves identifying strengths and developing the competitive advantages of regions based on the existing structure of the regional economy and innovation, as well as avoiding duplication of research and innovation activities in different regions. Smart specialization aims at stimulating economic growth and jobs in Europe, allowing each region to identify and develop its own competitive advantages. Smart specialization brings together local authorities, scientific communities, business structures and civil society to work on the implementation of long-term growth strategies supported by EU funds [3].

The smart specialization strategy sets priorities in order to create competitive advantages by developing and aligning the strong scientific and innovative sides of the region or industry with the business requirements; market development through cohesion, while avoiding duplication and fragmentation [15]. Regional innovation and smart specialisation strategies are treated as one of the key tools in implementing the concept of smart and sustainable growth. The strategies make it possible to focus investments on 
research and innovation in the areas showing the greatest economic and competitive potential of the regions [17]. The EU often declares an alignment between Cohesion Policy, Smart Specialization Strategies and the United Nations Agenda 2030 [22].

Smart specialization allows:

- to identify the unique functions and potential of each region;

- moving away from the practice of choosing priority sectors on an industrial basis only;

- to intensify public-private partnership processes, enabling the authorities to create comfortable conditions for entrepreneurs and employees to have appropriate employment conditions, thereby affecting the economic environment of the region and its competitiveness [20].

Smart specialization of regions aims to solve the following problems:

- enhancing the innovative and competitive potential of European regions as a basis for a sustainable growth model;

- enhancing interregional cooperation, which is a key element of a globalized economy;

- increasing attention to less developed regions;

- improving the collaboration in EU innovation policies and programs [11].

Reasonable specialization should enable regions to transform themselves technologically, focus on digitization, decarbonisation and modernization processes in industry. Today, smart specialization is often seen in the context of clustering of economic processes in EU Member States.

Ukraine has chosen its European integration path, which has a special place in Ukraine's foreign economic strategy. In the context of European integration, Ukraine seeks to achieve economic modernization, accelerate technological development, attract foreign investment, increase the competitiveness of the economy, strengthen its competitive position in the world market, in particular the EU. One of the important steps was the signing of the Association Agreement between Ukraine and the EU. The prospects of the European future of Ukraine depend on a large extent on the state regional policy of Ukraine.

Today, the main goal of state regional policy is to create conditions for the dynamic, balanced development of Ukraine and its regions, to ensure their social and economic unity, to improve the standard of living of the population, to adhere to socially guaranteed standards for each citizen regardless of their place of residence [21].

State regional policy in Ukraine is based on the principles of legality, cooperation, parity, openness, subsidiarity, coordination, unitarity, historical continuity, ethno-cultural development, sustainable development and objectivity.

According to the Law of Ukraine "On the Principles of State Regional Policy", the main priorities of state regional policy in Ukraine are [21]:

- stimulating and supporting local initiatives on the effective use of the regions' internal potential for creating and maintaining a complete living environment, improving the quality of life of people;

- reduction of territorial differentiation according to the regional human development index;

- formation of competitiveness of regions through development and implementation of programs and projects for enhancing the competitiveness of territories;

- stimulation of interregional integration, integration of regional economic, information, 
educational spaces into a single all-Ukrainian space, overcoming interregional alienation; - identification of problem areas in the regions and implementation of state measures to solve problems;

- creation of an effective system of environmental protection by taking into account the ecological component in the strategies of regional development, evaluation, equalization and reduction of technogenic and ecological load on the environment in the regions;

- introduction of effective instruments of state support for interregional integration, implementation of interregional programs and projects;

- formation of the legal framework necessary for the implementation of national regional policy, taking into account the documents of the Council of Europe and the European Union;

- improvement of material, financial, informational, personnel and other resources for the development of regions, promotion of the exercise of powers by local selfgovernment bodies;

- creation of effective mechanisms of representation of interests of regions at the national level.

These principles foresee the economic, environmental and social aspects of regional development in Ukraine, their observance contributes to reducing disparities in the development of regions, addressing issues of problem areas. Regional policy focuses on ensuring the competitiveness of regions and implementing programs to increase it. In order to ensure and increase the effectiveness of the implementation of regional policy in Ukraine at the national level, a system of regional cooperation between Ukraine and the EU has been developed. Ukraine cooperates with the EU in the aspects of regional development, in particular builds mutual understanding and common directions in the field of regional policy, establishes interaction of local and regional authorities with the EU within the EU Committee of the Regions, develops financial cooperation mechanisms for the implementation of individual projects, promotes Ukraine European regional associations such as the Assembly of European Regions, the Council of European Municipalities and Regions, the Association of European Border Regions. It is high time in Ukraine to intensify the introduction of smart specialization based on the effectiveness of its development and EU experience. Smart specialization in Ukraine is part of the EU's efforts to promote the development of Ukrainian regions and help to overcome the long-lasting economic downturn. For Ukraine, the advantage of this approach is joining the regions to the network of EU regions, attracting investors to the region, increasing the number of joint projects with the EU, supporting the regions in the process of economic transformation and adapting their capacities to market demands [29]. It is important to remember that the success of smart specialization implementation in Ukraine will depend on the synergistic effect of combining the efforts of government, business, the scientific environment and civil society. The smart specialization strategy may be separate, but may be integrated into national or regional scientific and innovation strategies. We consider the best option for integration, because then the synergistic effect increases and the tasks of scientific, innovative, regional and state development in general are solved comprehensively. This will not only increase regional competitiveness, create new jobs and improve the living conditions of households, but also provide additional financial support for regional development [3]. In Ukraine, it is advisable to set up a 
separate platform to advise regional representatives on the implementation of smart specialization strategies, following the example of the EU. In this way, representatives of the authorities, scientific community, business and the public will receive objective information and advice on the possibilities and forms of smart project organization in the regions, which will have a clear impact on the level of competitive development of the region and the state as a whole.

To ensure competitiveness, regional policy in Ukraine should be multidimensional and based on:

- the combination of national, regional and local development goals in Ukraine;

- intensification of regions' interest in self-development and increase of competitiveness level;

- possible diversification of areas of economic activity of regions;

- stimulating economic activity with a high level of competitiveness in the regions and cooperation between them at the interregional level;

- increasing the level of innovation of economic processes in Ukraine;

- the coherence of development policies at national and regional levels;

- establishing a clear responsibility of the authorities for implementing the policy of ensuring the competitiveness of the economy of the regions and the state.

In Ukraine it is important to ensure:

- the mechanism for state support for intensifying the cooperation of the regions of Ukraine with the regions of the EU Member States in order to adopt the experience and implement it in Ukraine and increase the level of competitive development;

- the establishing effective interregional communication between Ukraine and the EU countries;

- the increase of interest and expansion of financial capacities for realization of cooperation projects of regions of Ukraine and EU;

- the involvement of the public in the awareness of regional initiatives, which will at the same time be a type of public control and will discipline compliance with the planned steps at the regional level.

\section{Conclusions}

Strategies for regional competitive development in the context of global transformations are becoming increasingly relevant, given the opportunity to gain competitive advantage and to meet the challenges of the modern economy, based on knowledge, creativity and technology. Today, it is important to keep up with the trends dictated by the global economic environment as soon as possible for each entity, otherwise there are risks of being thrown to the periphery, which will slow down the pace of development. It is important to look for competitive reserves that can be discovered and used to build own competitive advantage. One of the options is to combine the potentials often found in integration processes, as well as to study and use foreign experience.

In the context of globalization, processes leading to the formation of new qualitative conditions of development take place. They require each economic entity to rethink its role in the economy of a region, country or world. Competitiveness is one of the 
characteristics that contributes to the survival in the economic environment today and lays the foundations for ensuring the right conditions in the future. The high competitiveness of the region testifies to the efficient organization and optimization of economic processes in it, given the availability of adequate infrastructure, effective work of the institutional component and directly effective work of market actors. The competitiveness of the region is formed in the conditions of competitive relations in the national and international markets and allows to respond in time to market changes. EU regional policy takes this into account, so the center has a category of regional competitiveness, as determined by the RCI calculation.

It is important that EU institutions, Member States and the public are involved in the development of EU regional policy, which can serve as an important experience for Ukraine. Another element of experience is the implementation of smart specialization foundations in regional development policy in Ukraine, which will maximize the opportunities and potential of the region and stimulate the activation of entrepreneurship development.

\section{References}

1. Alieva, A. (2016). State regulation of social and economic development of rural areas in Ukraine. Agricultural and Resource Economics, 2(1): 12-20. Available at: https://arejournal.com/are/article/view/20.

2. Annoni, P., and Dukstra, L. (2019). The EU Regional Competitiveness Index 2019. Available at: https://cohesiondata.ec.europa.eu/stories/s/Regional-Competitiveness-Index-2019/363v-4uq6.

3. Berezina, O. (2018). Smart specialization to improve household living conditions: a European experience. Economics and management, 4(32): 35-46.

4. Bilan, Y., Nitsenko, V., Ushkarenko, I., Chmut, A. and Sharapa, O. (2017). Outsourcing in international economic relations. Montenegrin Journal of Economics, 13(3): 175-185. https://doi.org/10.14254/18005845/2017.13-3.14.

5. Bilan, Yu. V., Nitsenko, V. S. and Samoilyk, Iu. V. (2017). Conceptual modeling of agri-food market development under economy's globalization. Scientific bulletin of Polissia, 3(11), 1: 54-61. https://doi.org/10.25140/2410-9576-2017-1-3(11)-54-61.

6. Bobrovsjka, O. ed. (2013). Ensuring the competitiveness of regions in the context of enhanced economic development. DRIDU NADU, Dnipropetrovsk, Ukraine.

7. Cambridge Econometrics (n.d.) A study on the factors of regional competitiveness. a draft final report for the European Commission Directorate-General Regional Policy. Available at: https://ec.europa.eu/regional_policy/sources/docgener/studies/pdf/3cr/competitiveness.pdf.

8. Cherkas, N. (2018). Structural determinants of regional competitiveness: the experience of EU regions. Regional economy, 1: 143-151.

9. EU expenditure and revenue. Available at: https://ec.europa.eu/budget/graphs/revenue expediture.html.

10. European Commission (n.d). The most competitive regions in Europe: capitals take it all. Available at: https://cohesiondata.ec.europa.eu/stories/s/The-most-competitive-regions-in-Europe-capitalsta/yt77-f74u.

11. European Commission (2017). Communication from the commission to the European Parliament, the Council, the European Economic and Social Committee and the Committee of the Regions, inclusive and sustainable growth. Available at: https://ec.europa.eu/regional_policy/sources/docoffic/2014/com_2017_376_2_en.pdf

12. European Commission (2019). Eurobarometer: Citizens' awareness and perception of EU Regional policy. Available

at: https://ec.europa.eu/regional policy/fr/information/publications/studies/2019/eurobarometercitizens-awareness-and-perception-of-eu-regional-policy.

13. European Regional Competitiveness Index (2016). Available at: 
https://ec.europa.eu/regional policy/en/information/maps/regional competitiveness/2016/\#3.

14. European Regional Competitiveness Index, (2019). Available at: https://ec.europa.eu/regional policy/en/information/maps/regional competitiveness/\#4.

15. European Union (2012). Guide to research and innovation strategies for smart specialisation (RIS 3). Luxembourg: Publications Office of the European Union. Available at: https://ec.europa.eu/regional policy/sources/docgener/presenta/smart specialisation/smart ris3 2012.pdf.

16. Ketels, Ch. (2016). Review of competitiveness frameworks. National Competitiveness Council. Dublin, Ireland.

17. Kogut-Jaworska M. and Ociepa-Kicińska, E. (2020). Smart specialisation as a strategy for implementing the regional innovation development policy - Poland case study. Sustainability, 12(19): 7986. https://doi.org/10.3390/su12197986.

18. Kujbida, V. and Fedulova L. (2019). New EU regional policy: lessons for Ukraine: an analytical note. NADU, Kyiv, Ukraine.

19. Kyrylov, Ju. (2015). Competitive development of the agrarian sector of the Ukrainian economy in the context of globalization: theory, methodology, practice (Doctoral dissertation). State higher education institution "Kherson State Agrarian University", Kherson, Ukraine.

20. McCann, P. and Ortega-Argilés, R. (2016). The early experience of smart specialization implementation in EU cohesion policy. European Planning Studies, 24(8): 1407-1427.

21. On the principles of state regional policy, (2015). Available at: https://zakon.rada.gov.ua/laws/show/156-19.

22. Polido, A., Pires, S. M., Rodrigues, C. and Teles, F. (2019). Sustainable development discourse in smart specialization strategies. Journal of Cleaner Production, 240: 118224. https://doi.org/10.1016/j.jclepro.2019.118224.

23. Prachenko, T. (2008). Factors and prerequisites for the formation of regional competitiveness. Available at: http://www.nbuv.gov.ua/portal/soc gum/vmsu/2008-01/08fvsyaiv.htm.

24. Raišienè, A. G., Yatsenko, O., Nitsenko, V., Karasova, N. and Vojtovicova, A. (2019). Global dominants of Chinese trade policy development: Opportunities and threats for cooperation with Ukraine. Journal of International Studies, 12(1): 193-207. https://doi.org/10.14254/2071-8330.2019/12-1/13.

25. Regional policy. Available at: https://en.wikipedia.org/wiki/Regional policy.

26. Rumyantseva, E. (2005). New economic encyclopedia. INFRA-M. Moscow, Russia.

27. Rybakova, O. (2009). Competition and Competitiveness: economic essence and factors of increase. Available at: http://www.nbuv.gov.ua/portal/Soc Gum/Nvamu ekon/2009 7/09rovaif.pdf.

28. Semiv, S., Berezivskiy, Y., Baranyak, I., Mulska, O. and Ivaniuk, U. (2021). Priorities and tools of regulation of external migration in the Carpathian region of Ukraine. Agricultural and Resource Economics, 7(2): 160-181. https://doi.org/10.51599/are.2021.07.02.09.

29. Smart Specialization tools will be used for the development of Ukrainian regions (2018). Available at: http://www.uiip.org.ua/https://decentralization.gov.ua/news/9614.

30. Vasyltsiv, T., Lupak, R., Kunytska-Iliash, M., Levytska, O. and Mulska, O. (2020). Instruments of regional policy for human resources conservation by means of regulation of external youth migration of rural territories of the Carpathian region. Agricultural and Resource Economics, 6(3): 149-170. https://doi.org/10.51599/are.2020.06.03.09.

31. Yatsenko, O., Nitsenko, V., Karasova, N., William, H.M. and Parcell, J. L. (2017). Realization of the potential of Ukraine - EU free trade area in agriculture. Journal of International Studies, 10(2): 258-277. https://doi.org/10.14254/2071-8330.2017/10-2/18.

32. Yatsenko, O., Nitsenko, V., Mardani, A., Streimikiene, D. and Tananaiko, T. (2019). Global risks of trade and economic cooperation of Ukraine with countries of the Northern American region. Montenegrin Journal of Economics, 15(3): 217-225. https://doi.org/10.14254/1800-5845/2019.15-3.16. 